\title{
A Case of Bilateral Malignant Ovarian Brenner Tumor
}

\section{Bilateral Malign Brenner Tümörü: Olgu Sunumu}

\author{
Emine Zeynep Uçar, Alper Karalök, Işın Üreyen, Tolga Taşçı, Derman Başaran, Osman Türkmen, \\ Mehmet Çelik, Taner Turan, Gökhan Tulunay
}

Etlik Zübeyde Hanım Kadın Hastalıkları Eğitim ve Araştırma Hastanesi, Jinekolojik Onkoloji Bölümü

Dergiye Ulaşma Tarihi:04.01.2016 Dergiye Kabul Tarihi: 06.06.2016 DOI: 10.5505/aot.2016.53825

\begin{abstract}
ÖZET
Giriș: Brenner tümörü nadir olarak görülen bir yumurtalık kanseridir ve tüm kanserlerin \%1'ni oluşturur. Bu tümörler genelde iyi huyludur ve Brenner tümörlerinin sadece \%1’i kötü (malign) karakterdedir. Nadir olarak görülen bilateral malign brenner tümörlü bir olguyu sunacağız.

Olgu: 55 yaşında hasta son bir aydır olan karında şişlik ve ağrı şikâyeti ile başvurdu. Hastanın fizik muayenesinde pelvik kitle ve asit sıvisı mevcuttu. Ultrasonografik incelemede yumurtalıktan kaynaklanan kitlesi mevcuttu. Ameliyat öncesi serum CA-125: 64 IU/ml'idi. Laparotomi yapılan hastanın bilateral yumurtalık kitleleri mevcuttu, frozen section incelemesi malign olan hastaya geride tümör kalmayacak şekilde evreleme cerrahisi yapıldı. FIGO 2009 evrelemesine göre evre IIIC olarak kabul edilen hasta adjuvan 6 kür platin bazlı kemoterapi aldı. On üç ay sonra bilateral ve çok sayıda akciğer metastazı gelişen hasta kurtarma kemoterapisi aldı. Sonrasında çok defa kemoterapi rejimleri almasına rağmen hastalığın ilerlemesi nedeniyle tanıdan 53 ay sonra hastalığından dolayı eksitus oldu.

Tartışma: İyi huylu lezyonlar basit eksizyonla tedavi edilebilir. Çok nadir görülmesinden dolayı malign brenner tümörünün cerrahi sonrası adjuvan tedavisi konusunda fikir birliği yoktur. Buna benzer yumurtalık patolojilerini içeren çok merkezli çalışmalar, bu hastalık ile olan bilgimizi artıracaktır.
\end{abstract}

Anahtar Kelimeler: Malign brenner tümörü, yumurtalık kanseri, sitoredüktif cerrahi, kemoterapi

\begin{abstract}
Background: Brenner tumor of ovary is a rare neoplasm which constitutes almost 1 percent of all ovarian tumors. These tumors are usually benign, with only $1 \%$ being malignant. Here, we report a very rare case of bilateral malignant Brenner tumor.

Case: A 55 year-old woman admitted to our center with complaints of abdominal distention and pain. Her physical examination was remarkable for pelvic mass and ascites. Sonographic examination showed a complicated pelvic mass of ovarian origin. Her preoperative serum CA-125 level was $64 \mathrm{IU} / \mathrm{ml}$. An exploratory laparotomy revealed bilateral ovarian masses and frozen section of the ovarian tumors was reported to be malignant. There was no peritoneal disease and she underwent a standard staging procedure. Final pathology revealed FIGO 2009 stage IIIC bilateral malignant Brenner tumor of the ovary. Patient received 6 cycles of platinum based chemotherapy. After 13 months of diagnosis multiple metastatic lesions in lungs were found and she underwent salvage chemotherapy. She received multiple chemotherapy regimens however disease progressed gradually and she succumbed to disease 53 months after initial diagnosis.
\end{abstract}

Discussion: In the vast majority of ovarian Brenner tumors, surgical resection provides a cure for benign disease. Owing to its low incidence there is not established adjuvant treatment algorithm for malignant ovarian Brenner tumors. Multicenter trials of ovarian cancer should aim to include this rare pathology to increase our knowledge. Keywords: Malignant brenner tumor, ovarian carcinoma, cytoreductive surgery, chemotherapy

\section{Giriş}

Brenner tümörü büyük oranda fibroma benzeyen, nadir olarak görülen bir yumurtalik tümörüdür ve tüm tümörlerin \%1,4-2,5'unu oluşturur (1). Mikroskobik incelemede belirgin olarak hiperplastik fibromatöz matriks arasına yayılmış epiteloid hücre adacıkları görülür. Epiteloid hücreler, uzunlamasına yarıklanan çekirdekleri nedeniyle kahve çekirdeği "coffee bean" yap1s1 gösterir. Brenner tümörünün basit Walthard hücre artıklarından köken aldığına inanılmasına rağmen, yüzey epitelinin rete ovarii ve ovaryan stromanın kendisi gibi farklı 
dokulardan da kaynaklanabileceği gösterilmiştir (2).

Brenner tümörünün genel olarak benign olarak kabul edilmesine rağmen son birkaç dekatta olguların \%1'inin malign olduğu rapor edilmiştir (1). Brenner tümörü genel olarak hormon salgilamaz. Fakat son yillarda yapılan yayınlarda postmenopozal endometrial hiperplazi gelişen bazı hastalardaki hiperplazi brenner tümörünün östrojenik salg1 yapmasıyla ilişkilendirilmiştir (3). Brenner tümörünün virilizm ile ilişkili olabileceği de rapor edilmiştir (4).

Brenner tümörlerinin çoğu cerrahiye adaydır. Genelde sinırlı bir tümör olması dolayısıyla yerinin tespit edilmesi kolaydır ve çevreleyen dokuyu etkilemez. Cerrahi rezeksiyon çoğu hastada tedavi edicidir ve semptomların gerilemesine yardımcı olur. Malign Brenner tümörleri ise çevre dokuyu etkileyebilir ve diğer yapılara yayılım gösterebilir ancak çok nadir görüldüğünden standart tedavi oluşturulamamıştır. Farklı kemoterapi rejimleri düşük başarı oranları ile uygulanmaktadır. $\mathrm{Bu}$ olgu sunumunda da nadir olarak görülen ve görüntüleme tetkikleriyle tanınamayan bilateral malign brenner tümöründen bahsedilmektedir.

\section{Olgu sunumu}

55 yaşında kadın hasta, kasık ağrısı ve karında şişme şikâyeti ile merkezimize başvurdu. Yapilan ultrasonografik incelenmede sol yumurtalık, 150x84 mm büyüklügünde düzgün sınırlı içinde soliter ekolu alanlar içeren kitle lezyonu ve kitlenin alt kısmında 33x34 mm'lik kistik alan bulunmaktaydı. Sağ adneksiyel alanda 110x90 mm büyüklüğünde solid-kistik alanlar içeren komplike kitle mevcuttu. Batın alt kadranda $30 \mathrm{~mm}$ serbest sivi saptandi. Tümör belirteçlerinden CA125: 64 IU/ml'di.

Hastaya laparotomi yapıldı. İntraoperatif gözlemde batında $600 \mathrm{cc}$ seröz nitelikte serbest sıvı bulunmaktaydı, serbest sıvıdan sitoloji için örnek alınd1. Sol yumurtalıkta 20x15 cm rüptüre sağda $10 \times 8 \mathrm{~cm}$ rüptüre tümoral kitle mevcuttu. Hastaya total abdominal histerektomi, bilateral salpingooforektomi, omentektomi, appendektomi, alt para-aortik bölgede şüpheli lenf nodu eksizyonu operasyonu yapıld. Cerrahi ile tam olarak maksimal debulking sağlandı. Hastanın postoperatif patolojisi bilateral malign brenner tümörü, barsak mezosundaki lenf nodunda metastatik karsinom ve batın sıvısında malignite yönünden şüpheli hücreler olarak raporlandı. FIGO (International Federation Gynaecology Obstetrics)'a göre Evre IIIC olarak tanımlandı. Hastaya 6 kür sisplatin ve paklitaksel kemoterapisi verildi. Tedavi sonrasi alt-üst abdomen tomografi normal olarak raporlandi. 13 ay sonra hasta boyunda şişlik yakınmasıyla başvurdu. Lenf nodu biyopsisi yapıldı ve hastanın sistemik taranmasında akciğer tomografisinde "her iki akciğer alanında yaygın ve en büyükleri $12 \mathrm{~mm}$ çapa ulaşan çok sayıda solid metastatik kitle izlendi. Boyundaki skalen lenf nodu biyopsi patolojisi nonspesifik lenfadenit" olarak raporlandı. Hastaya 6 kür sisplatin, etoposid kemoterapisi verildi. Tedavi sonras1 tam cevap veren hasta tedaviden 6 ay sonra yapilan ultrasonografide mesane sol altta $52 \times 43 \mathrm{~mm}$ solid kitle oluşumu mevcuttu. Altüst abdomen tomografisinde; sol adneksiyel bölgede $55 \times 50 \mathrm{~mm}$ büyüklügünde kısmen düzensiz konturlu, septalı, kistik solid komponentli kitle, retroperitoneal alanı dolduran ve konglomere lenf nodlarina ait olduğu düşünülen yumuşak doku kitlesi izlendi ve solda böbrek hidronefrotik ve afonksiyoneldi. Hastaya pelvik eksternal radyoterapi verildi. Tedavi sonrası alt-üst abdomen tomografisi değerlendirilen hastanın pelviste sol adneksiyel alanda 50x45 mm çapta kitle ve paraaortik alanda büyümüş konglomere lenf nodları izlendi. Yapılan tedaviye rağmen tümörde ilerleme izlenen hasta opere edildi. Pelvisteki nüks kitle ve paraaortik bölgedeki konglomere lenfatik metastazlar çıkarıldı ve maksimal debulking sağlandı. Adjuvan BEP (bleomisin+ etoposid+ sisplatin) kemoterapisi verildi. 9 ay sonra akciğer ve alt-üst abdomen tomografilerinde; pelviste $66 \times 64 \mathrm{~mm}$ boyutlarında solid oluşum, sağ akciğer orta lobda ve sol bazalde büyüğü $48 \mathrm{~mm}$ çapa ulaşan metastaz ile uyumlu nodüler lezyonlar, karaciğer içinde en büyüğü $37 \times 32 \mathrm{~mm}$ olan çok sayıda lezyonlar, sol sürrenal lojda $53 \times 50$ $\mathrm{mm}$ yumuşak doku kitleleri saptandi. Hastaya palyatif 5 kür sisplatin, adriamisin ifosfamid planland. Kemoterapiye cevap vermeyen hastaya oral etoposid tedavisi başland 1 ve bu tedaviden 2 ay sonra karaciğer yetmezliği nedeni ile hasta exitus oldu. 


\section{Tartışma}

Yumurtalık tümörleri 2013 yılında yapılan WHO siniflandırılmasina göre; epitelyal stromal tümörler, germ hücreli tümörler, sexkord stromal tümörler ve ikincil (metastatik) tümörler olarak gruplara ayrılmıştır. Brenner tümörü epitelyal stromal tümörlerin transizyonel hücreli tümörler alt grubunda yer alır.

Brenner tümörü, genelde benign olsa da bir kısmı borderline veya malign olabilir (1). Brenner tümöründe malign tümör tanımı ilk kez Von Numers tarafindan 1945 yllinda yapılmıştır. Malign Brenner tümörünün kriterleri o zamandan beri oluşturulmaya çalışılmaktadır ve 1973 yılında Hall ve Campbellin sıraladığı kriterler şunlardır: 1) malign histopatolojik bulguların varlığı 2) malign komponent ile benign Brenner tümör arasında açık bir ilişki varlığı 3) müsinöz kistadenomun olmamas1, varsa da benign ve malign Brenner tümöründen kesin bir şekilde ayrı olmas1 4) Brenner tümörün epitelyal elementlerinin stromal invazyonun gösterilmesidir (1).

Malign brenner tümörünün en sık görülme yaş1 medyan 55'dir ve başvuru esnasında en sik gözlenen semptom karın ağrısıdır (5). Bizim olgumuz da literatür ile uyumlu olarak 55 yaşında idi ve karın ve kasık ağrıs1 semptomlarıyla başvurdu. Brenner tümörünün nonspesifik komponentlerinden dolay1 görüntüleme yöntemlerinden ultrasonografi veya tomografi ile tanınmasi zordur (6). Olgumuzda da ovaryan kitle preoperatif olarak gösterilmiş fakat tümörün tipi konusunda bir yorum yapılamamıştır. Benign Brenner tümörleri düzgün kenarl1, sert veya fibromatöz gri, beyaz veya açık sarı renkte yüzeylidir. Doku kalsifik depolanmadan ötürü sertleşir. Borderline Brenner tümörleri kistiktir ve bir ya da çok loküle uzanan karnıbahar şeklinde papillomatöz uzantılar içerir. Malign Brenner tümörleri solid veya mural nodüller içeren kistler şeklinde olabilir ve genelde ayırt edici özellikleri yoktur (7). Brenner Tümörlerinin \%4-14'de endometrial hiperplazinin eşlik ettiği gösterilmiştir (8). Olgumuzda hastada endometrial patoloji saptanmamıştır. Malign brenner tümörlerinin \%10'unda kitleye asit eşlik eder(11), bizim olgumuzda da $600 \mathrm{cc}$ seröz nitelikte asit mayi bulunmaktaydı.

Malign brenner tümörlerin başlangıç tedavisi diğer epitelyal yumurtalık kanserlerindeki gibi cerrahidir (9). Definitif cerrahi total abdominal histerektomi+ bilateral salpingo-ooferektomi+ bilateral pelvik para-aortik lenf nod diseksiyonu ve omentektomiyi içeren sitoredüktif cerrahidir (9). Sunulan olguda tam bir sitoredüktif cerrahi yapılmıştır. Cerrahi sonrası adjuvan tedavi yaklaşımında tam bir fikir birliği yoktur.

Benign brenner tümörleri genelde tek taraflı olarak görülmesine karşın malign brenner tümörleri bilateral ve kistik yapıların daha fazla olduğu solid-kistik kitleler olarak gözlenir (10). Olgumuzda kitle, bilateral ve komplike solid-kistik olarak izlenmekteydi. Gezginç ve ark yaptığ 1 malign brenner vaka serisinde olguların $\% 46.2$ 'de tümörün evresi FIGO'a göre evre IIIC'di ve bu hastaların hepsi adjuvan tedavide paklitaksel+ karboplatin kemoterapisi almıştır (11). Evre IIIC olan bu hasta grubunun \%16.6's1 hastal1ktan dolayı kaybedilmiştir. Olgumuzda da, hasta cerrahi tedavi sonrası paklitaksel + sisplatin tedavisi almış ve rekürrenslerinde çeşitli cerrahi ve kemoterapi tedavileri sonrasinda 53 ay takip edilip bu hastalıktan dolay1 kaybedilmiştir. Malign brenner tümörü olan 10 hastayı içeren bir çalışmada kemoterapinin rekürrenste umut verici olduğu (12) yazılsa da bu konuda daha çok çalışmaya ihtiyaç vardır. Malign Brenner tümörü nadir görülen epitelyal orijinli yumurtalık malignitesidir. Genel olarak kabul edilen cerrahi yaklaşım sitoredüktif cerrahidir. Adjuvan tedavi konusunda fikir birliği yoktur. Cerrahi genelde erken evrelerde küratif olsa da malign Brenner tümörleri çevre veya uzak dokulara metastaz yapabilir ve hastalar bu hastalıktan dolayı kaybedilebilir. $\mathrm{Bu}$ tümör konusundaki bilgi birikiminin ve tedavi yaklaşımının yazılan olgu sunumları ve olgu serileri ile artacağını umuyoruz.

\section{Referanslar:}

1. Yamamoto R, Fujita M, Kuwabara M, Sogame M, Ebina Y, Sakuragi N, Kato H, Fujimoto S. Malignant Brenner tumors of the ovary and tumor markers: case reports. Jpn J Clin Oncol. 1999; 29: 308-13

2. Lamping JD, Blythe JG. Bilateral Brenner tumors: a case report and review of the literature. Hum Pathol. 1977; 8: 583-5 
3. Kühnel R, Rao BR, Stolk JG, van Kessel H, Seldenrijk CA, Willig AP. Estrogen synthesizing rare malignant Brenner tumor of the ovary with the presence of progesterone and androgen receptors in the absence of estrogen receptors. Gynecol Oncol. 1987; 26: 263-9

4. de Lima GR, de Lima OA, Baracat EC, Vasserman J, Burnier M Jr. Virilizing Brenner tumor of the ovary: case report. Obstet Gynecol.1989; 73: 895-8

5. Driss M, Mrad K, Dhouib R, Doghri R, Abbes I, Ben Romdhane K. Ascitic fluid cytology in malignant Brenner tumor: a case report. Acta Cytol. 2010; 54: 598-600

6. Moon WJ, Koh BH, Kim SK et al. Brenner tumor of the ovary: CT and MR findings. J Comput Assist Tomogr. 2000; 24: 72-76

7. Clemet PB, Young RH. Ovarian Surface Epithelial Stromal Tumors. In: Mills SE, editor. Sternberg's Diagnostic Surgical Pathology. 5th ed. Philadelphia: Lippincott Williams and Wilkins, A Wolters Kluwer business; 2010; 2278-308
8. Seldenrijk CA, Willig AP, Baak JP et al. Malignant Brenner tumor. A histologic, morphometrical, immunohistochemical,and ultrastructural study. Cancer. 1986; 58: 754-760

9. Verleye L, Ottevanger PB, van der Graaf W, Reed NS, Vergote I, Gynaecological Cancer Group(GCG) of European Organisation for Research and Treatment of Cancer (EORTC), et al. EORTC-GCG process quality indicators for ovarian cancer surgery. Eur J Cancer 2009; 45: 517e26

10. Ben Aissia N, Sadfi A, Youssef A et al. Malignant Brenner's tumor particularities and coverage. Tunis Med. 2004; 82: 701-707

11. Gezginç K, Karataylı R, Yazici F, Acar A, Çelik Ç, Çapar $\mathrm{M}$ et al. Malignant Brenner tumor of the ovary: analysis of 13 cases. Int J Clin Oncol 2012; 17: 324-9

12. Han JH, Kim DY, Lee SW, Park JY, Kim JH, Kim YM, Kim YT, Nam JH. Intensive systemic chemotherapy is effective against recurrent malignant Brenner tumor of the ovary: An analysis of 10 cases within a single center. Taiwan $\mathbf{J}$ Obstet Gynecol. 2015; 54: 178-82 